\title{
Online business networking experience research on ecommerce entrepreneurs
}

\author{
Ramona-Alexandra NEGHINĂ \\ Webecom S.R.L., Bucharest, Romania \\ ramona@webecom.ro \\ Valentin-Andrei MĂNESCU \\ Webecom S.R.L., Bucharest, Romania \\ mail@valentinmanescu.ro \\ Mihaela-Rodica GANCIU \\ Energomontaj S.A., Bucharest, Romania \\ mihaella.ganciu@gmail.com \\ Dragoș-Georgian ILIE \\ University of Bucharest, Bucharest, Romania \\ dragos@webecom.ro \\ Gheorghe MILITARU \\ University Politehnica of Bucharest, Bucharest, Romania \\ gheorghe.militaru@upb.ro
}

\begin{abstract}
In a globalized economy, marketing performance is needed in order to be competitive and also for being successful on the market. Currently entrepreneurs have access to a big variety of tools and also the increase of networking platforms can help ecommerce entrepreneurs to gather a lot of useful information and know-how for improving their businesses. Our main objective is to identify which are the most important needs of ecommerce entrepreneurs in order to communicate with other business owners activating in the ecommerce industry. The secondary objective is to identify what features an online networking platform should have, so it can become an important tool for growing the marketing performance of each member using the networking platform. The research was made using a focus group composed of 15 participants. All participants are business owners who manage at least one online store, selling goods in the local or international market for at least 3 years. The results of the qualitative research made, were that entrepreneurs who are trying to establish a new business partnership, use classical forms of communication, such as email, phone calls, meetings but they believe that online communication would be beneficial for their business because it can be less time consuming and more efficient for finding new business partners or relevant know-how. We discovered that entrepreneurs wish to learn from the practical experience of other business owners to improve the marketing performance through innovation and creativity. The research conducted has identified the key elements of a business networking platform for entrepreneurs. The main elements required include privacy, security, sharing relevant know-how and elements that can create an efficient collaborative environment. We also discovered that local entrepreneurs do not use or know a business networking platform that meets their demands and expectations for sustaining an effective business development.
\end{abstract}


Keywords: online business networking, business to business collaboration, e-commerce business, business communication requirements, e-commerce supply chain, online know-how sharing

\section{Introduction}

In the past decade, eCommerce has been developing constantly and has not yet reached its full potential. This argument can be a solid motif of using an online networking platform which can bring real benefits to the ecommerce entrepreneurial community, a dynamic community that confronts change very often because of new software technologies.

The proposed research has an important contribution because it analyzes the requirements of an online networking platform, a networking solution that would facilitate business interactions of ecommerce entrepreneurs. At the same time, an online networking platform can for ecommerce entrepreneurs can bring an important contribution not only for eCommerce entrepreneurs, but IT service providers, online advertisers, delivery companies, online payment processors, eCommerce marketplaces and any kind of third-party business that could improve the overall performance and efficiency of an online shop.

The main research questions are: What are the main motifs of using a networking platform for ecommerce entrepreneurs? What are the issues and benefits for ecommerce entrepreneurs if using more online networking? What are the requirements of ecommerce entrepreneurs for using the online networking platform?

The main aspects identified are the demand of a time efficient approach of networking because ecommerce entrepreneurs not often find the necessary time to pursue prospective business partners. Also, the research conducted intents to determinate the problems that might emerge when adopting online networking in the detriment of classical networking.

\section{Literature Review and Hypotheses Online entrepreneurship}

In recent years a new form of entrepreneurship has emerged alongside with the Information and Communication Technology (ICT) development. The emergence of the Internet and development of the Information and Communication Technology has offered a proper environment for the expansion of online entrepreneurship (Matlay \& Westhead, 2005).

The term of online entrepreneur, digital entrepreneur or e-entrepreneur defined by Prakash (2009) refers to a person who conducts an Internet based venture and all their economic transactions take place online, via the Internet. It is necessary to define the online entrepreneur as a person who establishes and conducts a venture on the Internet. An online entrepreneur encompasses activities of a regular entrepreneur, but the mode of operation and the processes are more technologically based.

Online entrepreneurs need to possess specific skills. Entrepreneurial characteristics, such as previous work experience or risk taking may not be relevant for an online entrepreneur (Daniel \& Anwar, 2014). A good knowledge of the basics in web programming languages such as HTML, CSS, PHP, JavaScript are of use for an entrepreneur who has an online business. Some of the technical knowledge mentioned above may not be so relevant nowadays considering an entrepreneur could easily buy software solutions.

According to McFarland (2017) when it comes to the education of an online entrepreneur, he/she can rely on two focal aspects, more exactly: a heavy reliance on 
technology and self-learning. Self-learning for an online entrepreneur implies individual learning, objectives and outcomes, planning and organizing the learning skills, evaluating and creating meaning from it (Candy et al., 1994). Active learning is crucial for entrepreneurs in order to enable problem solving, self-reliance and self-reflection (McFarland, 2017).

An entrepreneur needs to know information about management, marketing and also have a basis of economic notions. Any other kind of inclinations, passions or abilities can lead to an entrepreneur ready for innovation (Driessen \& Zwart, 2018). Moreover, online entrepreneurs, having basic programming and technical knowledge can benefit the business because it can help them to understand better the technical principals and processes of the business.

\section{Online networking}

Many interactions between online entrepreneurs take place by using traditional forms of communication such as emails, video-conferencing, instant messaging, face-to-face meetings (Matlay \& Westhead, 2005). The development of the new forms of communication and networking, such as online platforms or other Internet-based interactive technologies, such as video-conferences have removed many barriers in the way of efficient communication and networking between online entrepreneurs.

In order to take advantage of the virtual environment created by e-Commerce and the Internet, small businesses could access a wide range of online informational sources (Matlay $\&$ Westhead, 2005). Online entrepreneurs learn to work in the digital age in a networked environment such as social networking sites (Facebook, Twitter, LinkedIn), virtual meetings, virtual learning environments, emails or chat sessions (McFarland, 2017).

Online communication networks provide platforms upon which entrepreneurs or firms can interact, communicate and collaborate (Turban et al., 2002) with other entrepreneurs or companies that can provide services which can further develop the business of the online entrepreneurs, such as delivery companies that can bring the products to the end customers, online payment system providers, online advertising companies and so on.

However, in the internet of things world, tech entrepreneurs are working to break traditional entrepreneurship barriers. In fact, tech and online entrepreneurs focus on identifying opportunities, build trust and shift perceptions in order to establish a competing business and increase the probability of attracting news investments (Bayarasli, 2012). Online entrepreneurs around the world are making use increasingly of electronic communications facilities in their daily lives. This mostly involves interactions between parties who have never formerly met. Consequently, communications networks of all kinds are being exploited in new path to conduct business, to facilitate remote working and to create other virtual shared environments (Jahanshahi, et al., 2011).

Entrepreneurs have long considered interpersonal networking key for promoting their new ideas, especially in high tech circles. Communication through online social networks, such as Facebook, LinkedIn, Twitter, Myspace and blogs has become a major means of staying in touch with business partners, complementing, and even substituting established communication channels such as e-mail and phone (Gloor et al., 2013). 
Online and social media networking is becoming increasingly important also for business (Gloor et al., 2013). Particularly for e-entrepreneurs introducing new business ideas, online cooperation is a promising strategy as it enables the partners to create more attractive product offers and represents a basis for more efficiently and effectively communicating and distributing their product offers (Kollmann \& Häsel, 2008).

\section{Ecommerce characteristics and hypotheses}

The paper analyzes the needs of ecommerce entrepreneurs when it comes to online networking experience. Thus, it is important to define ecommerce and its characteristics. Electronic commerce is a business model in which transactions take place over electronic networks, mostly the Internet. It includes the process of electronically buying and selling goods, services, and information (Turban et al., 2018).

Electronic commerce, or e-commerce, refers to economic activity that occurs online.

E-commerce includes all types of business activity, such as retail shopping, banking, investing and rentals. Electronic commerce draws on technologies such as mobile commerce, electronic funds transfer, supply chain management, Internet marketing, online transaction processing, electronic data interchange (EDI), inventory management systems, and automated data collection systems. Modern electronic commerce typically uses the World Wide Web at least at one point in the transaction's life-cycle, although it may encompass a wider range of technologies such as e-mail, mobile devices social media (Kavyashree et al., 2013).

The eCommerce business model has increased in the past decade worldwide, separating more and more form the traditional retail outlets and is becoming an important component of the global sales of growing enterprises. The online entrepreneurship is becoming a more significant part of today's business world (Prakash, 2009) and ecommerce is creating a new way of doing business, one that is connecting producers, sellers, and customers via technology in ways that have never been possible before.

The result is a whole new set of companies built on business models that are turning traditional methods of commerce and industry (Zimmerer \& Scarborough, 2015). As these companies discover new, innovative ways to use the Internet, computers, and communications technology to connect with their suppliers and to serve their customers better, they are creating a new industrial order. In short, e-commerce has launched a revolution (Evans \& Volery, 2001).

The research is hypotheses are the following: 1. Online entrepreneurs need an online networking platform, 2. It is difficult to find a unitary networking solution, 3. Online entrepreneurs prefer traditional networking in the detriment of online networking, 4. Both women and men entrepreneurs have the same preferences of networking channels. The Internet is a powerful medium that can provide the business development services much needed by entrepreneurs and the key to the future of online business lies in adaptation to change and implementation of technology-based solutions (Evans \& Volery, 2001).

The research is exploratory and the objectives are: 1. To acknowledge if an online networking platform is needed, 2. To identify and classify the networking communication methods from the eCommerce entrepreneurial perspective, 3. To identify the issues that might 
arise when adopting a networking platform, 4. To determinate the expectations of online entrepreneurs for the networking platform.

\section{Methodology}

The research purpose is to determinate and understand the requirements of online networking between entrepreneurs. The qualitative research method analyzes the key aspects involved in using an online networking platform, in order to demonstrate the contribution brought to improving interactions and networking of the online entrepreneurial community.

For collecting the research data, a focus group composed of 15 people was organized. The focus group method was adopted because it is an informal method of gathering relevant data from the participants. All the participants in the focus group use the same eCommerce software for their online stores. The name of the eCommerce software provider was anonymized due to privacy issues and it will be referred as company W. The names of interviewees were anonymized due to privacy related issues and the participants in the focus group they will be referred with their initials of their names. The online shops owned by the focus group members have various activity domains, such as fishing and haunting equipment, toy stores, electrical equipment, optics, medical devices, honey and apiculture. The ecommerce entrepreneurs were chosen from various activity domains in order to demonstrate the applicability of networking experiences and establishing partnerships, regardless the activity domain of any online shop.

The focus group was addressed a series of questions. The questions were addressed to the focus group composed of 15 ecommerce entrepreneurs, of different ages, both women and men, from different activity domains in the eCommerce niche. Given the fact that the purpose of this research is to better understand the utility of online networking platform, the focus group was one of the best research techniques. The qualitative research method chosen was focus group due to the fact that it emphasizes the needs and beliefs of the focus group members and it aims to analyze and demonstrate the importance and benefits of online communication between eCommerce entrepreneurs.

All the people involved in the focus group have at least one online store and they operate in different activity domains. They were chosen from different activity domains that will be mentioned later in this paper due to the purpose of demonstrating that the need of communication and establishing partnerships is the same, no matter the activity of domain their online businesses operate in.

The data obtained after the focus group interview has processed using qualitative research software, NVIVO in order to corelate and find the common aspects of the interviewee's opinions and remarks, as well as the different perspectives of the research theme proposed.

\section{Research results and discussions}

The common characteristic of the participants is the use of W. software platform for operating an online store. The focus group session had a series of questions that were addressed to the participants by the moderator. The questions were used to determinate the 
needs, reequipments, expectations and issues of the online entrepreneurs when it comes using an online networking platform.

Table 1 - Focus group and online stores characteristics

\begin{tabular}{|c|c|c|c|c|c|c|c|c|}
\hline Respondent & Gender & Age & $\begin{array}{c}\text { Google } \\
\text { Category }\end{array}$ & $\begin{array}{c}\text { Category } \\
\text { Level }\end{array}$ & $\begin{array}{c}\text { No. of } \\
\text { products }\end{array}$ & $\begin{array}{c}\text { No. of } \\
\text { Employees }\end{array}$ & $\begin{array}{c}\text { TO (EUR) } \\
2017\end{array}$ & $\begin{array}{c}\text { Profit } \\
\text { (EUR)2017 }\end{array}$ \\
\hline P.G. & Female & 50 & $\begin{array}{c}\text { Baby Toys \& } \\
\text { Activity } \\
\text { Equipment }\end{array}$ & 2 & 3.096 & 5 & 395.579 & 50.052 \\
\hline R.I. & Male & 27 & $\begin{array}{l}\text { Mobile Phone } \\
\text { Accessories }\end{array}$ & 4 & 8.445 & 2 & 450.864 & 157.662 \\
\hline D.A. & Male & 45 & Fishing & 3 & 8.538 & 1 & 35.405 & 0 \\
\hline R.B. & Male & 50 & $\begin{array}{l}\text { Household } \\
\text { Appliance } \\
\text { Accessories }\end{array}$ & 2 & 3.413 & 3 & 74.903 & 11.914 \\
\hline I.M. & Female & 42 & $\begin{array}{l}\text { Work Safety } \\
\text { Protective } \\
\text { Gear }\end{array}$ & 2 & 579 & 2 & 166.069 & 22.286 \\
\hline D.I. & Male & 28 & $\begin{array}{c}\text { Computer } \\
\text { Components }\end{array}$ & 3 & 1.367 & 3 & 42.972 & 14.090 \\
\hline R.R. & Male & 61 & $\begin{array}{c}\text { Power \& } \\
\text { Electrical } \\
\text { Supplies }\end{array}$ & 2 & 15.082 & 7 & 2.641 .826 & 74.407 \\
\hline A.B. & Male & 28 & $\begin{array}{l}\text { Baby Toys \& } \\
\text { Activity } \\
\text { Equipment }\end{array}$ & 2 & 7.851 & 1 & 112.910 & 14.609 \\
\hline N.D. & Male & 49 & $\begin{array}{c}\text { General } \\
\text { Purpose } \\
\text { Athletic } \\
\text { Equipment }\end{array}$ & 3 & 1.494 & 0 & 48.250 & 16.914 \\
\hline M.M. & Female & 28 & Gift Giving & 3 & 216 & 8 & 60.234 & 3.890 \\
\hline R.O. & Female & 56 & $\begin{array}{c}\text { Home } \\
\text { Automation } \\
\text { Kits }\end{array}$ & 3 & 30 & 10 & 27.066 & 12.758 \\
\hline A.P. & Male & 53 & Eyeglasses & 4 & 456 & 22 & 441.420 & 22.266 \\
\hline R.P. & Female & 40 & $\begin{array}{l}\text { Vital Signs } \\
\text { Monitors }\end{array}$ & 4 & 80 & 6 & 26.916 & 8.225 \\
\hline N.C. & Female & 38 & Honey & 4 & 200 & 1 & 6.282 & 1.256 \\
\hline M.P. & Female & 49 & Gift Giving & 3 & 785 & 1 & 7.166 & 0 \\
\hline Average & - & 42,93 & - & - & $3.442,13$ & 4,80 & $302.524,13$ & $27.335,27$ \\
\hline
\end{tabular}

Note: no.=number, TO=turnover, EUR=euro exchange rate of 4,5038 from 31.12.2017 from the BNR (Romania's National Bank)

Source: Author's own research

Table 1 presents the ecommerce entrepreneurs of the focus group, their names being anonymized by using the initial letters of their names, the gender of the focus group members, the total number of products in their online stores, number of employees, the turnover and profit in 2017. 
The first question in the focus group interview addressed by the moderator was "What is the activity domain for your online shop?". In Table 1 the activity domains of each of the 15 online shops owned by the eCommerce entrepreneurs of the focus group were divided by using the Google category attribute of items in the online stores, based on the Google product taxonomy (Google LLC, 2018). The Google online shop category is an international classification for the online store activity domain used for search engine optimization and better online advertising results.

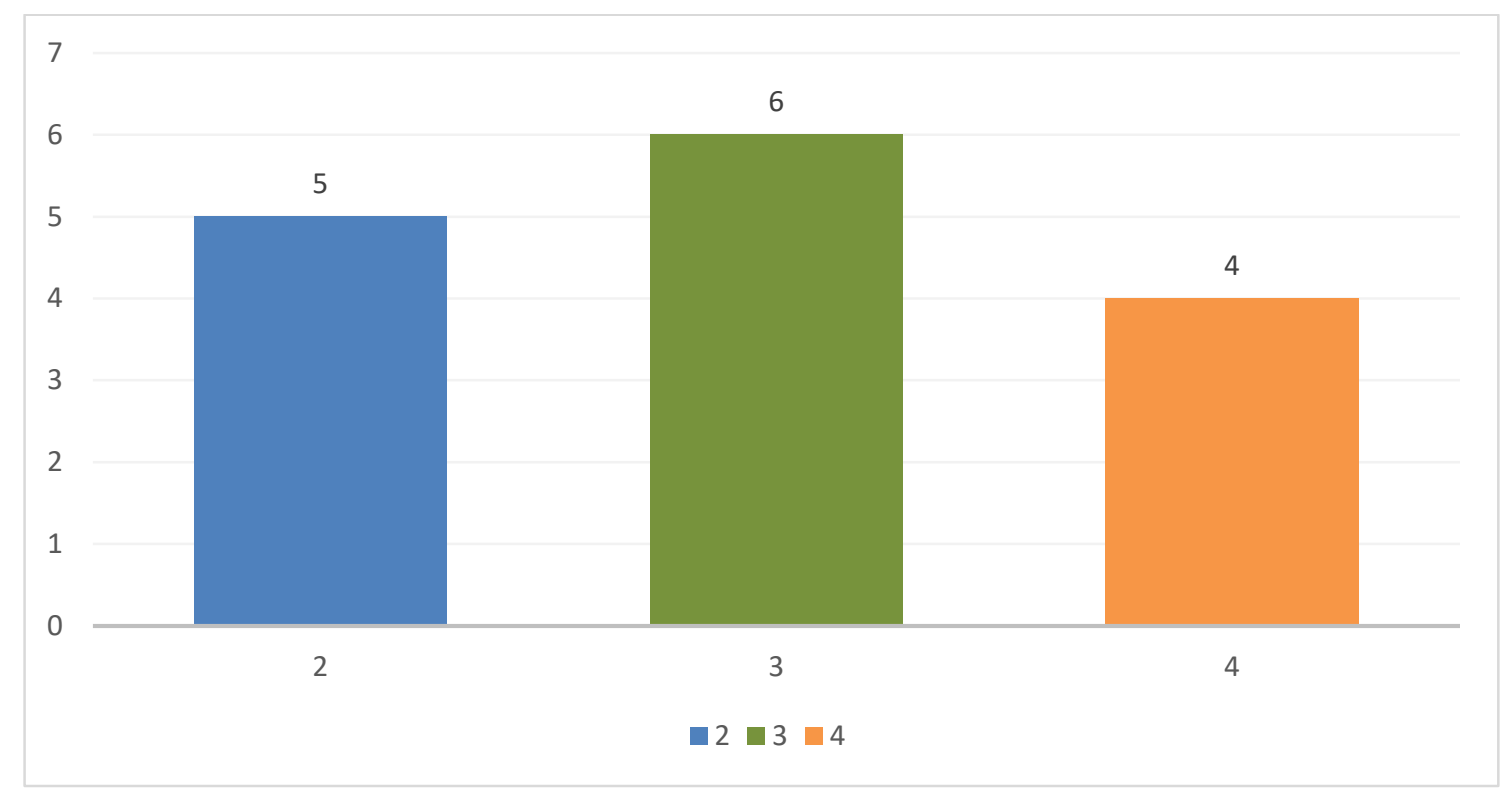

Figure 1 - Google online store category level occurrence

Source: Author's own research

Figure 1 illustrates Google's online store category classification. Google's category classification is a multi-level classification starting from level one to level five. The first level indicates a more generic activity domain category and as the category level increases the more niched and specific the activity domain of the online store is.

The second question addressed to the focus group was "What communication methods do you use for business networking?". This question was addressed in order to determinate and understand the need of an online networking platform and the current state of entrepreneurial networking methods. Table 2 presents the most frequently used communication forms by the online entrepreneurs interviewed, namely e email, phone calls, meetings and instant messaging such as online chat, WhatsApp and Skype.

As the results in Table 2 demonstrate, out of 15 responders, all of them use email as the primary communication method, thus making email correspondence the most relevant. Given the fact that online entrepreneurs have to take care of a lot of tasks, email 
correspondence can help them to postpone responding to emails and help entrepreneurs to keep a history of the email correspondence.

The result in Table 2 show that, all of the 15 respondents mentioned that they use phone calls for communicating with their business partners. Given the fact that all of the interviewees affirmed that they use phone calls demonstrates the importance of this communication method because is a more personal way of communicating with business partners and information can be transmitted much faster via a phone call. Also, online entrepreneurs who are less than 50 years old tend to use more online communication methods, such as e-mails, instant messaging (WhatsApp, Facebook Messenger, online chat) for networking purposes than entrepreneurs who are over 50 years old.

Table 2 - Ecommerce entrepreneurs communication methods used in networking

\begin{tabular}{|c|c|c|c|c|c|c|}
\hline Respondent & Gender & Age & E-mails & Phone calls & Instant Messaging & Meetings \\
\hline P.G. & Female & 50 & $\mathrm{X}$ & $\mathrm{X}$ & $\mathrm{X}$ & $\mathrm{X}$ \\
\hline R.I. & Male & 27 & $\mathrm{X}$ & $\mathrm{X}$ & $\mathrm{X}$ & \\
\hline D.A. & Male & 45 & $\mathrm{X}$ & $\mathrm{X}$ & & \\
\hline R.B. & Male & 50 & $\mathrm{X}$ & $\mathrm{X}$ & $\mathrm{X}$ & $\mathrm{X}$ \\
\hline I.M. & Female & 42 & $\mathrm{X}$ & $\mathrm{X}$ & $\mathrm{X}$ & $\mathrm{X}$ \\
\hline D.I. & Male & 28 & $\mathrm{X}$ & $\mathrm{X}$ & & $\mathrm{X}$ \\
\hline R.R. & Male & 61 & $\mathrm{X}$ & $\mathrm{X}$ & $\mathrm{X}$ & \\
\hline A.B. & Male & 28 & $\mathrm{X}$ & $\mathrm{X}$ & $\mathrm{X}$ & \\
\hline N.D. & Male & 49 & $\mathrm{X}$ & $\mathrm{X}$ & $\mathrm{X}$ & \\
\hline M.M. & Female & 28 & $\mathrm{X}$ & $\mathrm{X}$ & $\mathrm{X}$ & \\
\hline R.O. & Female & 56 & $\mathrm{X}$ & $\mathrm{X}$ & $\mathrm{X}$ \\
\hline A.P. & Male & 53 & $\mathrm{X}$ & $\mathrm{X}$ & $\mathrm{X}$ \\
\hline R.P. & Female & 40 & $\mathrm{X}$ & $\mathrm{X}$ & $\mathrm{X}$ & $\mathrm{X}$ \\
\hline N.C. & Female & 38 & $\mathrm{X}$ & $\mathrm{X}$ & $\mathrm{X}$ & \\
\hline M.P. & Female & 49 & $\mathrm{X}$ & $\mathrm{X}$ & \\
\hline N.e. X
\end{tabular}

Note: $\mathrm{X}$ marks the choice of each respondent

Source: Author's own research

Figure 2 presents the most frequently used networking communication methods used by the eCommerce entrepreneurs sorted by gender in order to analyse if the communication methods used are different depending on the gender. 


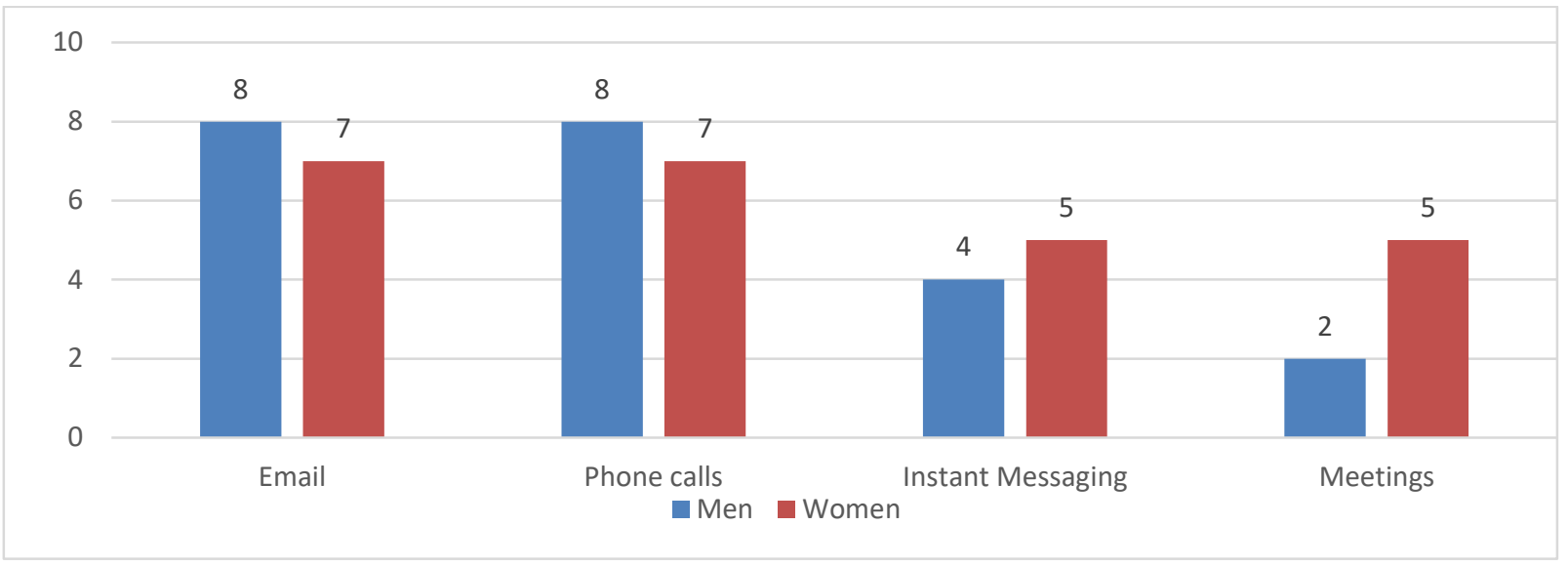

PICBE $\mid 393$

Figure 2 -Ecommerce entrepreneurs networking channels sorted by gender

Source: Author's own research

Figure 3 illustrates the issues, benefits and expectations of the focus group entrepreneurs when using the online networking platform. The third question addressed to the focus group members was meant to identify a few issues that might arise when using more online communication methods for networking purposes, more precisely "Name a few issues that might arise if you use more online communication for networking purposes than traditional methods of communication".

When asked to identify a few issues encountered when using online communication, 7 out of 15 people mentioned about not being able to see and understand the non-verbal communication of their business partners as presented in Figure 3. Not understanding the message was another issue identified by the participants. Some other respondents, more exactly 5 out of 15 people, did not identify any issue when it comes to online communication. By analyzing the answers of the respondents, the main issues were of using online communication for business networking purposes were identified and are presented in Figure 3.

The fifth question addressed to the interviewees during the focus group meeting was "Can you identify the benefits of using an online networking platform by communicating with other online business owners?". After analyzing the responses of the focus group members, the benefits identified were improving their management style, sharing know-how with other online entrepreneurs, sharing ideas, expertise, advice and finding relevant information that would improve their online store activity as presented in Figure 3. The second tendency observed from analyzing the responses of the focus group was impartiality. Out of 15 people interviewed, 4 were not so sure about the benefits of sharing know-how and improving management style by using an online networking platform.

In order to identify the expectations about the networking platforms, the eCommerce entrepreneurs of the focus group were addressed the following question: "What would you like to find in a networking platform?". The question aimed to understand the features that would be useful and of interest for the online entrepreneurs who are going to use an online networking platform.

The responses of the focus group members were very diverse but some of the similar features of the online networking platform mentioned by the participants were contact 
details for each user profile, such as phone number, email address, company name, field of activity, experience, useful advice as presented in Figure 3.

Figure 3 presents the main tendencies identified by analyzing the answers of the respondents, such as contact details of other online entrepreneurs, especially online entrepreneurs who work in the same domain activity and the finding distributors and service providers, such as delivery companies and any other service or product provider that could improve the business development of an online store. Still, the most prominent tendency being finding more contact information about other online entrepreneurs.

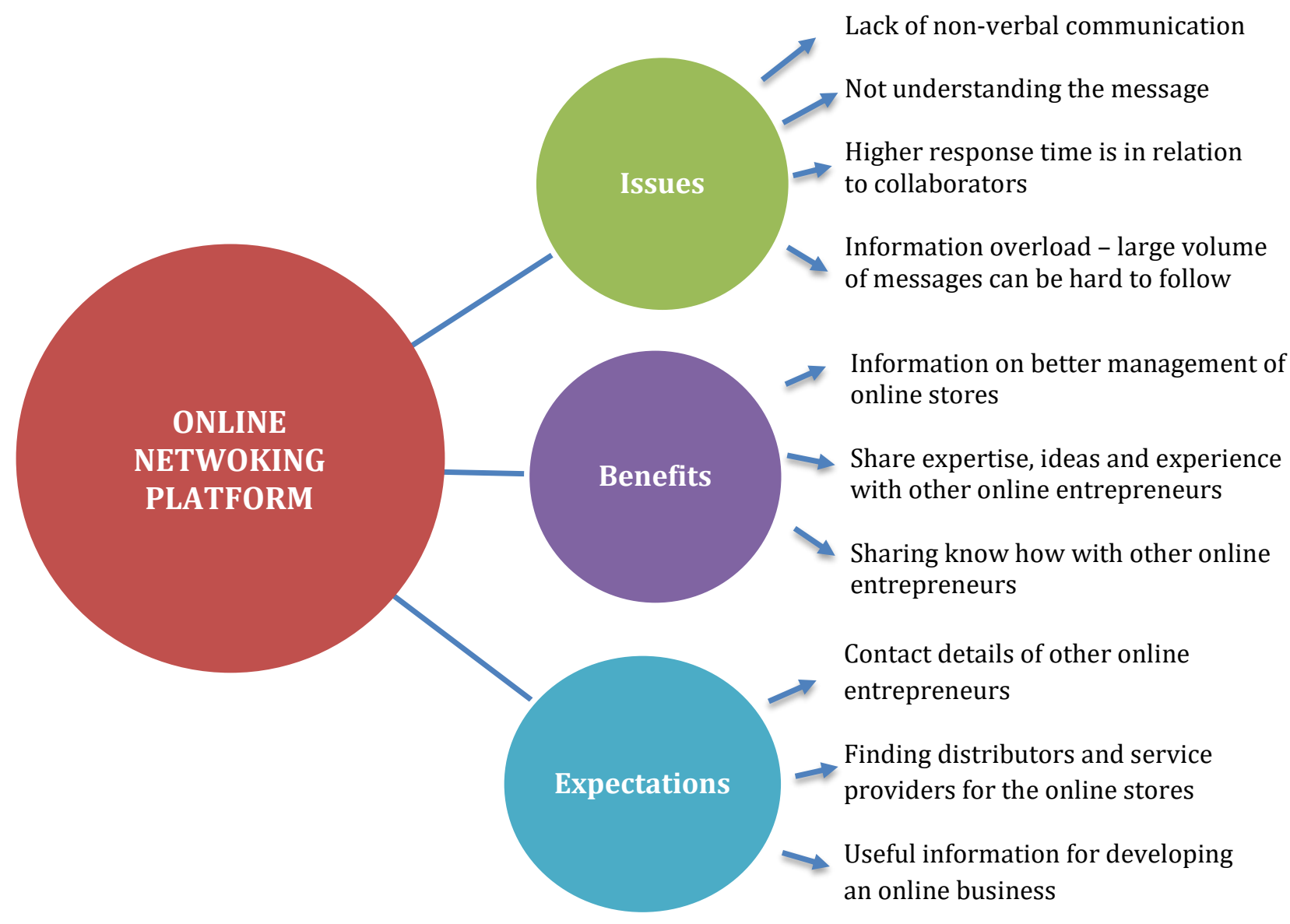

\section{Figure 3 - Online networking platform issues, benefits and expectation}

Source: Author's own research

Online entrepreneurs tend to collaborate, share experience and knowledge with entrepreneurs that work in the same domain as they do. This can be explained by the fact 
that people tend to look identify themselves as being part of a group and it can be applied in the case of the online entrepreneurial networking platform.

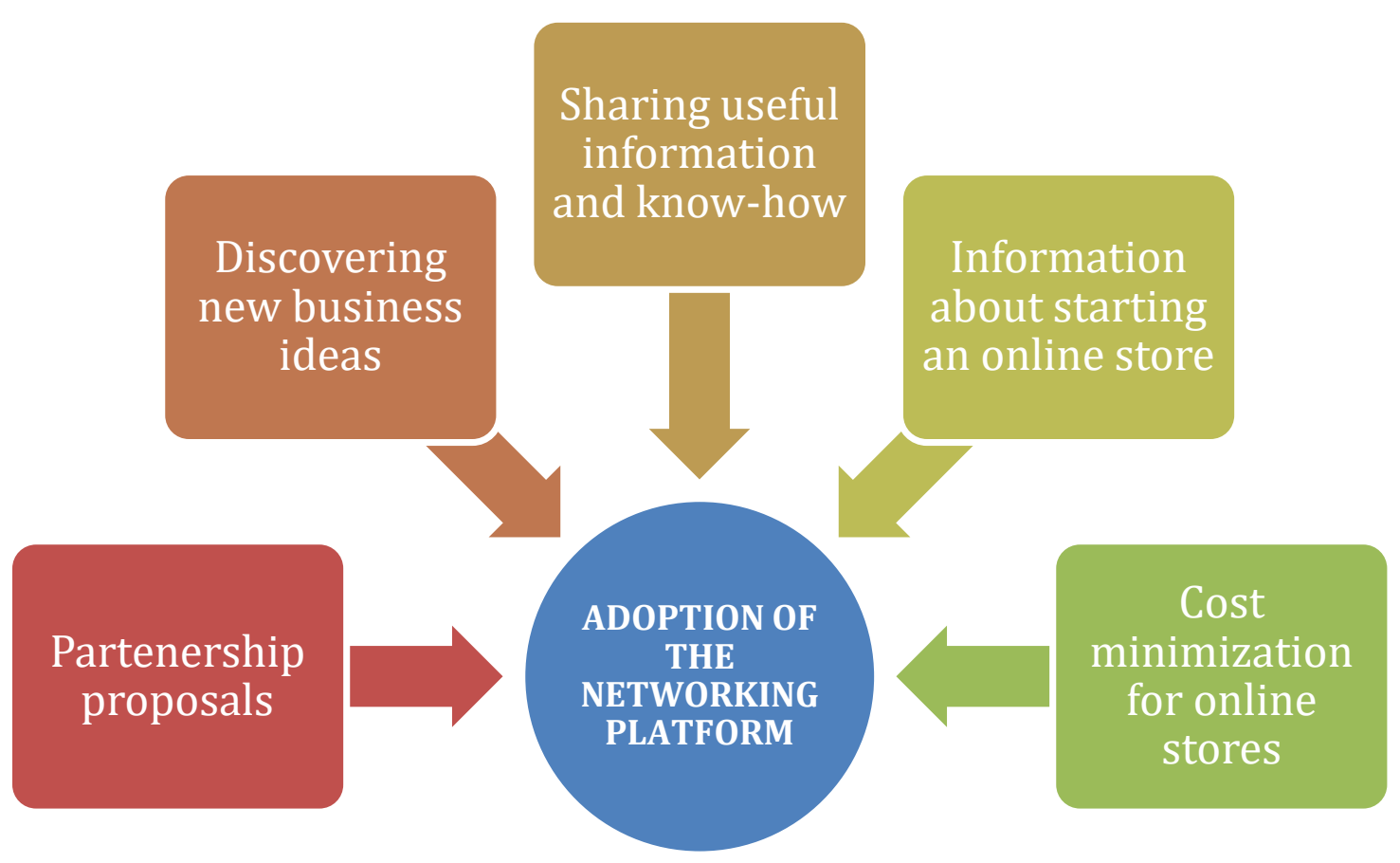

PICBE | 395

Figure 4 - Key elements on adopting of the online networking platform

Source: Author's own research

Figure 4 presents the key elements of adopting the online networking platform. In order to identify the key elements, the ecommerce entrepreneurs in the focus group were asked the following question "What would determinate you to be active and involved in a networking platform with other entrepreneurs?"

By analyzing the interviewees answers, the key elements identified that would determinate the online entrepreneurs to use the online communication platform were useful information, sharing experience with other online entrepreneurs. Out of the 15 respondents, 8 mentioned about sharing useful information and know-how, such as accounting, legal advice and framework for online stores, eCommerce news, online store administration insights, cost minimization and so on, the most relevant motifs identified are presented in Figure 4.

The second key element identified is interacting and sharing experience with other online entrepreneurs. Out of the 15 respondents, 6 have mentioned about the desire to interact and communicate. The motif behind the affirmations of the respondents might be explained by the need of individuals to be part of a group, a basic need identified even in 
Maslow's basic needs pyramid. At the same time, another motif can be developing a successful online store and business by learning from the experience of other entrepreneurs.

Another question addressed to the focus group was "What information would help you to use the platform?". By analyzing the answers of the focus group participants, the key communication methods for helpful information on how the platform works and how it should be used are email communication, training sessions, a user guide, one to one meetings and workshops as presented in Table 3, for each respondent. Thus, informing online entrepreneurs about how to use the platform can be done in various ways, both by using online communication such as newsletters, or sending an electronic user guide, as well as workshops, training.

Figure 5 presents the learning methods preferred by the eCommerce entrepreneurs when learning how the networking platform works. The results are sorted out by gender.

Table 3 - Learning methods of using the online networking platform

\begin{tabular}{|c|c|c|c|c|c|}
\hline Respondent & Gender & Newsletters & User guide & Trainings & Workshops \\
\hline P.G. & Female & $\mathrm{X}$ & $\mathrm{X}$ & & $\mathrm{X}$ \\
\hline R.I. & Male & $\mathrm{X}$ & & & $\mathrm{X}$ \\
\hline D.A. & Male & $\mathrm{X}$ & & $\mathrm{X}$ & $\mathrm{X}$ \\
\hline R.B. & Male & $\mathrm{X}$ & $\mathrm{X}$ & & \\
\hline I.M. & Female & $\mathrm{X}$ & & $\mathrm{X}$ & $\mathrm{X}$ \\
\hline D.I. & Male & $\mathrm{X}$ & $\mathrm{X}$ & & \\
\hline R.R. & Male & $\mathrm{X}$ & & & $\mathrm{X}$ \\
\hline A.B. & Male & $\mathrm{X}$ & $\mathrm{X}$ & $\mathrm{X}$ & $\mathrm{X}$ \\
\hline N.D. & Male & $\mathrm{X}$ & $\mathrm{X}$ & & \\
\hline M.M. & Female & $\mathrm{X}$ & $\mathrm{X}$ & $\mathrm{X}$ & $\mathrm{X}$ \\
\hline R.O. & Female & $\mathrm{X}$ & & $\mathrm{X}$ & $\mathrm{X}$ \\
\hline A.P. & Male & $\mathrm{X}$ & $\mathrm{X}$ & $\mathrm{X}$ & $\mathrm{X}$ \\
\hline R.P. & Female & & $\mathrm{X}$ & & $\mathrm{X}$ \\
\hline N.C. & Female & $\mathrm{X}$ & & $\mathrm{X}$ & $\mathrm{X}$ \\
\hline M.P. & Female & $\mathrm{X}$ & $\mathrm{X}$ & $\mathrm{X}$ & $\mathrm{X}$ \\
\hline
\end{tabular}

Note: X marks the choice of each respondent

Source: Author's own research

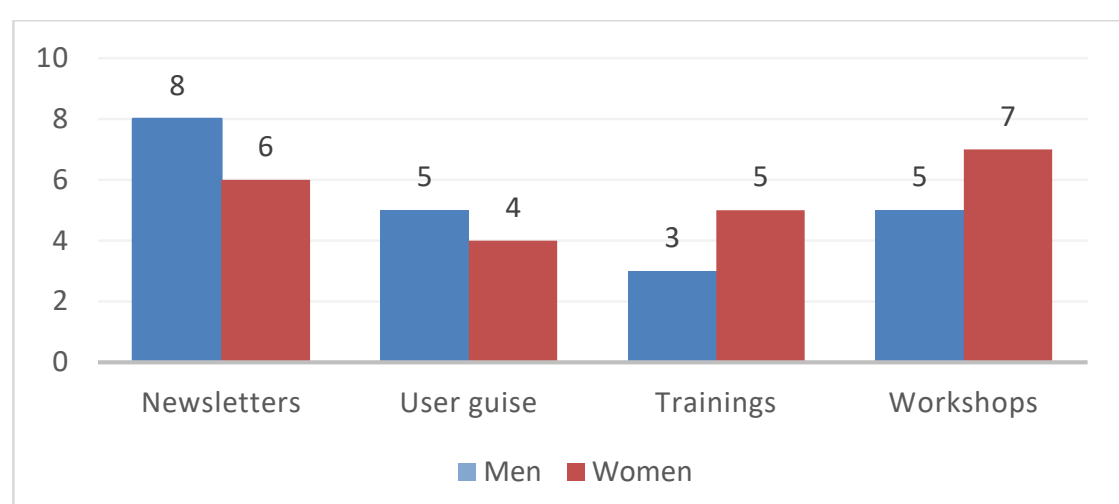

Figure 5 - Frequency of identified learning methods for the networking platform

Source: Author's own research 
The research is hypotheses that were validated are: 1. Online entrepreneurs need an online networking platform, 2. It is difficult to find a unitary networking solution and the hypotheses that did not validate are 3. Online entrepreneurs prefer traditional networking in the detriment of online networking, 4. Both women and men entrepreneurs have the same preferences of networking channels.

PICBE | 397

\section{Conclusions}

To conclude, online entrepreneurs play a pivotal role in the eCommerce business model because they seek business opportunities in order to further develop their online store. Given the fact that many business models operate exclusively online and even the more traditional businesses models are shifting their attention and reach the online environment, even if just for a simple presentation website or for a more complex eCommerce software solution, the development and implementation of an online networking platform can bring real benefits.

Undoubtedly, eCommerce is a complex and dynamic domain and ecommerce entrepreneurs are looking for solutions that could ease the networking process and searching for the right business partners that could bring added value to their online store. Thus, a networking platform will be helpful because it can be time efficient and online entrepreneurs could find the potential partners they are looking for, from delivery companies that would transport the products to the end client, online payment system providers, to ecommerce entrepreneurs that operate in the same activity domain and whom can share ideas and expertise with.

As for the limitations of the research, the qualitative analysis is an analysis of perception and by being a perceptual analysis is not as accurate compared to a quantitative research. The qualitative research was used because the case study focuses on the perspectives and needs beliefs of the focus group member rather than on factual reports. Also, the focus group was composed of a limited number of participants, more exactly 15 online entrepreneurs and the research was conducted in a single company, mentioned in the study as W.

As a recommendation, the online communication platform should not represent the only communication method. The best practice should be a mix between the using the online communication platform combined with more classical methods of communication such as meetings, phone calls. Further research should focus more on the online entrepreneurs and traits as well as their beliefs and ways of communicating and networking practices in order to improve the processes and technologies of online communication used in online business. The present research is the starting point of a future quantitative research for understating online entrepreneurial needs.

\section{References}

Bayarasli, E. (2012). Entrepreneurs Save the World. World Policy journal, 29(2), 89-96.

Candy, P. C., Crebert, G., \& O'Leary, J. (1994). Developing Lifelong Learns Thourgh Undergradutae Education. Canberra, Australia: Australian Government Publishing Service. 
Daniel, E., \& Anwar, M. (2017). Ethnic entrepreneurs and online home-based businesses: an exploratory study.Journal of Global Entrepreneurship Research, 7, 11-20.

Driessen , M. P., \& Zwart, P. S. (2010). The role of the entrepreneur in small business succes: The Entrepreneurship Scan Retrieved from : http://www.ondernemerstest.nl/wpcontent/uploads/2010/03/ICSBv5.pdf

Evans, D., \& Volery, T. (2001). Online business development services for entreprenerus: an exploratory study. Entrepreneurship and Regional Development, 1(13), 250-333.

Gloor, P., Dorsaz, P., Fuehres, H., \& Vogel, M. (2013). Choosing the right friends - predicting success of startup entrepreneurs and innovators through their online social network structure. International Journal Organisational Design and Engineering, 3(1), 67-85.

Google LLC. (2018). Definition of the Google product category. Retrieved from https://support.google.com/merchants/answer/6324436?hl=en

Jahanshahi, A. A., Nor, K. M., Hozhabri, A. A., \& Khaksar, S. S. (2011). From Mobile To Mobile Commerce: An Overview In The Indian Perspective. 2nd International Conference on Business and Economic Research Proceeding (pp. 758-770). Langkawi, Malaysia:Conference Master Resources.

Kavyashree, N., Niranjanamurthy, M., Jagannath, S., \& Dharmendra, C. (2013, June). Analysis of E-Commerce and M-Commerce: Advantages, Limitations and Security issues. International Journal of Advanced Research in Computer and Communication Engineering, 2(5), 2360-2370.

Kollmann, T., \& Häsel, M. (2008). Cross-channel cooperation: On the collaborative integration of online and offline business models of e-entrepreneurs and traditional SMEs. International Journal Entrepreneurship and Small Business, 6(2), 212-229.

Matlay, H., \& Westhead, P. (2005). Virtual Teams and the Rise of e-Entrepreneurship in Europe. International Small Business Journal, 23(3), 279-302.

McFarland, K. (2017). Entrepreneurship education and experimental e-learing: A literature review. 44th Annual Conferece Association for Business Simulation and Experiential Learning Proceedings (pp.268-273). Myrtle Beach, SC: ABSEL.

Prakash, D. (2009). A Conceptual Framework for Describing Online Entrepreneurship. Journal of Small Business \& Entrepreneurship, 3(22), 275-283.

Turban, E., King, D., Lee, J., Warketin, M., \& Chung, M. (2002). Electronic Commerce: A Managerial Perspective.Upper Saddle River, NJ: Prentice Hall.

Turban, E., Outland, J., Lee, J. K., Liang, T.-P., \& Turban, D. (2018). Electronic Commerce 2018 - A Managerial and Social Networks Perspective. Cham, Switzerland: Springer.

Zimmerer, T., \& Scarborough, N. (2015). Essentials of Entrepreneurship and Small Business Management. London, United Kingdom: Pearson. 